\title{
Lytic Plaque Formation and Variation in Virus Titre among Strains of Penicillium_chrysogenum
}

\author{
By P. A. LEM KE \\ Department of Biological Sciences, Carnegie-Mellon University, \\ Pittsburgh, Pennsylvania, I5213, U.S.A. \\ AND \\ C. H. NASH AND SARAH W. PIEPER \\ Antibiotic Manufacturing and Development Division, \\ Eli Lilly and Company, \\ Indianapolis, Indiana, 46206, U.S.A. \\ (Received 31 October 1972; revised 3 January 1973) \\ SUMMARY \\ Strains of Penicillium chrysogenum derived from a virus-infected culture have \\ been investigated for reduction in virus titre. These strains were obtained following \\ treatment with either heat $\left(74^{\circ} \mathrm{C}\right)$ or specific antimetabolites. Virus titres were \\ measured with a combination of immunological and radiochemical assays. One \\ strain was cured of the mycophage and exhibited an increased growth rate and \\ stability. Other strains, which show an apparent reduction in intracellular virus \\ titre, actually released increased levels of virus from cells. Lytic plaques developed \\ when infected strains were grown on an unbuffered, high lactose-containing \\ medium, and virus titres could be correlated with plaque formation. All strains, \\ regardless of virus titre, retained the ability to synthesize penicillin.
}

\section{INTRODUCTION}

The fungus Penicillium chrysogenum is infected with a virus containing double-stranded ribonucleic acid (Banks et al. 1969; Lemke \& Ness, 1970). Biochemical and biophysical characterization of this mycophage and its component nucleic acid has been pursued in several laboratories (Buck, Chain \& Himmelweit, I97I; Wood \& Bozarth, 1972; Nash et al. 1973). The biology of this virus has not been extensively studied, yet the biological implications of a virus in $P$. chrysogenum are many. Strains of $P$. chrysogenum are known to vary spontaneously with regard to growth rate, sporulation efficiency, and antibiotic productivity (Backus \& Stauffer, 1955). Such instability among cultures of $P$. chrysogenum is perhaps related, at least in part, to variation in virus titre. Penicillium chrysogenum is a haploid organism and has been adapted for formal genetic analysis (Sermonti, 1957). This fungus should, therefore, provide a model experimental system for extensive biological characterization of a virus in a eukaryotic cell. In this paper we report that virus content in $P$. chrysogenum is variable. Strains heavily infected with virus are shown to exhibit lysis, and a stable strain cured of virus is described. 


\section{METHODS}

Strains and growth media. A mutant culture of Penicillium chrysogenum (E-I5), derived from NRRL I95I (Elander, I967), was used as the control strain for this investigation. The E-I 5 culture and strains obtained from it were maintained on a minimal sporulation medium containing purified lactose, I2 g; $\mathrm{NaNO}_{3}, 3 \mathrm{~g} ; \mathrm{MgSO}_{4} \cdot 7 \mathrm{H}_{2} \mathrm{O}$, o.I g; $\mathrm{KH}_{2} \mathrm{PO}_{4}, 60 \mathrm{mg}$; $\mathrm{CuSO}_{4} \cdot 5 \mathrm{H}_{2} \mathrm{O}, 2 \mathrm{mg}$; $\mathrm{Fe}\left(\mathrm{NH}_{4}\right)_{2}\left(\mathrm{SO}_{4}\right)_{2} \cdot 6 \mathrm{H}_{2} \mathrm{O}, 20 \mathrm{mg}$; NaCl, $10 \mathrm{~g}$; agar, $25 \mathrm{~g}$; distilled water, $1000 \mathrm{ml}$. This medium was used as a routine plating medium. All cultures were grown at $25{ }^{\circ} \mathrm{C}$. Spore inocula were grown either in a complex vegetative medium (Vanderhaeghe, Claesen, Vlietinck \& Parmentier, 1968) or in a minimal vegetative medium (Lemke \& Ness, 1970). Either spores ( $10^{7}$ cells) or vegetative cells (mycelia after $72 \mathrm{~h}$ of growth in complex vegetative medium) were used to inoculate $500 \mathrm{ml}$ Erlenmeyer flasks containing $100 \mathrm{ml}$ of a complex fermentation medium described by Moss \& Cole (1964). Growth in this medium proceeded for 3 to 8 days at $25{ }^{\circ} \mathrm{C}$ on a rotary shaker (250 rev./min).

Antiviral treatment. In order to reduce virus titre, spores from the control culture (E-I 5) were either exposed to high temperature or grown in the presence of selected compounds. Heat treatment was conducted in the following manner. Spores were collected in distilled water containing 0.I \% polyoxyethylene sorbitan.mono-oleate (Sigma Chemical Co., St. Louis, Missouri, U.S.A., PI754), adjusted to a titre of $10^{7}$ spores $/ \mathrm{ml}$, and incubated at $74{ }^{\circ} \mathrm{C}$ in a gyratory ( $25 \mathrm{rev} . / \mathrm{min}$ ) water-bath shaker (New Brunswick Scientific, New Jersey, U.S.A., G 176 ). Samples ( $\mathrm{I} \mathrm{ml}$ ) were removed at $10 \mathrm{~min}$ intervals up to $2 \mathrm{~h}$ and plated without dilution. Survivors of treatment at the highest dosage were subcultured on to sporulation medium and grown for 2 weeks at $25^{\circ} \mathrm{C}$. Spores were again collected and treated a second time. After three successive heat treatments, strains were examined for reduction in virus titre.

A series of antimetabolites and antiviral compounds were tested for their toxicity to Penicillium chrysogenum. The sensitivity of the control culture to a particular compound was determined according to procedures described previously (Lemke, I969). Spores $\left(10^{6} / \mathrm{ml}\right)$ were incubated at $27^{\circ} \mathrm{C}$ for $48 \mathrm{~h}$ in minimal vegetative medium containing a sublethal concentration of a given compound (see below). Mycelia were collected by centrifugation $(1000 \mathrm{~g}$ ) and washed twice with $\mathrm{I} 0 \mathrm{ml}$ distilled water. These cells were macerated for $90 \mathrm{~s}$ in a Waring blender at high speed. The macerate was plated with serial dilution on to sporulation medium. Spores from isolated colonies were subcultured, and strains were again treated with the same compound before evaluating virus titre. Compounds surveyed include aranotin (Dr N. Neuss, Lilly Research Laboratories), 5-azacytidine (Calbiochem, La Jolla, California, U.S.A.), 6-azauridine (Nutritional Biochemicals Corporation, Cleveland, Ohio, U.S.A.), cycloheximide (Sigma Chemical Co.), ethidium bromide (Calbiochem), mycophenolic acid (Imperial Chemical Industry), and pyrazomycin (Dr K. Gerzon, Lilly Research Laboratories).

Preparation of extracts. Forty grams of mycelia from $72 \mathrm{~h}$ cultures grown in the complex fermentation medium were washed twice with cold distilled water, suspended in $20 \mathrm{ml}$ tris buffer (0.02 $\mathrm{M}, \mathrm{pH} \mathrm{8.0)} \mathrm{containing} 0.0 \mathrm{I} \mathrm{M}-\mathrm{MgCl}_{2}$ and disrupted in a French pressure cell at $20000 \mathrm{lb} / \mathrm{in}^{2}$. Cellular debris was removed by centrifugation for $15 \mathrm{~min}$ at $30000 \mathrm{~g}$. Virus particles were pelleted from the supernatant by centrifugation (Beckman L3-50) for $4 \mathrm{~h}$ at $100000 \mathrm{~g}$. This pellet was resuspended in $0.5 \mathrm{ml}$ of tris buffer. The presence of virus was determined by the Ouchterlony double-diffusion method.

Immunological assay. Virus was isolated from the control culture and purified by isopycnic zonal centrifugation in sucrose and in caesium chloride (Nash et al. 1973). Purified virus 
was adjusted with phosphate buffer, $0.02 \mathrm{M}, \mathrm{pH} 7.0$, containing $0.01 \mathrm{M}-\mathrm{MgCl}_{2}$ to a titre of $\mathrm{I} \cdot 4 \mathrm{mg}$ virus $/ \mathrm{ml}$ buffer. This stock suspension of purified mycophage $\left(E_{260}=10\right)$ served as the antigen (AgM).

Rabbit antiserum to purified mycophage $\left(A b_{R M}\right)$ was prepared by injecting a single animal intramuscularly with four ro mg doses of virus over a 20-day period. Each dose was combined with an equal volume of complete Freund's adjuvant (Difco, Detroit, Michigan, U.S.A.) and the rabbit was sacrificed on the 3oth day.

Specificity of antiviral antiserum was determined by the Ouchterlony double-diffusion assay (Horwitz \& Scharff, I969), with Kallestad immunodiffusion plates. No serological reactions occurred with normal rabbit serum or serum from rabbits injected with complete Freund's adjuvant.

Virus titre in fungal extracts was estimated either by the agar immunodiffusion assay or by direct immunological precipitation of radioactively labelled virus. In this study, virus was labelled with tritium by the addition of uracil- $6{ }^{-} \mathrm{H}$ (Amersham/Searle, Arlington Heights, Illinois, U.S.A., $1000 \mathrm{mCi} / \mathrm{mmole}$ ) to fermentation medium at a concentration of I $\mu \mathrm{Ci} / 2 \mathrm{ml}$. Mycelia were harvested by centrifugation and washed with tris buffer. Extracts were prepared as mentioned above. Labelled virus from these extracts was precipitated directly with antiserum $\left(0.2 \mathrm{ml} \mathrm{Ab_{RM }} / \mathrm{ml}\right.$ extract). Virus from broth samples was precipitated either by the addition of rabbit antiviral serum $\left(0.2 \mathrm{ml} \mathrm{Ab_{ \textrm {RM } }} / \mathrm{ml}\right.$ broth) or by addition of an equal volume of $10 \%$ trichloroacetic acid. All precipitates were washed repeatedly with phosphate buffer $(0.02 \mathrm{M}, \mathrm{pH} 7 \cdot 0)$. Radioactivity was then measured with a Packard TriCarb liquid scintillation spectrophotometer (Model 3375) with an external standard. Aquasol (New England Nuclear, Boston, Massachusetts, U.S.A.) was used as a scintillation medium.

Biological assay. In order to test for lytic plaque formation, spores of Penicillium chrysogenum were plated densely ( $10^{5}$ to $10^{6} /$ plate) on to medium containing purified lactose, I $80 \mathrm{~g}$; peptone, Io g; agar (Baltimore Biological Laboratories, Cockeysville, Maryland, U.S.A.), $20 \mathrm{~g}$; and distilled water, $1000 \mathrm{ml}$. Cultures of $P$. chrysogenum were incubated at $25^{\circ} \mathrm{C}$. On this medium, devised by Borré and co-workers (I97I), viral plaques were formed in two other species of Penicillium, $P$. citrinum and $P$. variabile.

Assay for antibiotic. Culture broths were assayed for penicillin by reaction with hydroxylamine (Boxer \& Everett, 1949). This assay was modified for the Technicon autoanalyser and had a precision of $\pm 1 \%$.

RESULTS

In order to reduce virus titre among strains of Penicillium chrysogenum, spores of this organism were exposed to heat or germinated in the presence of specific compounds. The sensitivity of a virus-infected culture to heat $\left(74^{\circ} \mathrm{C}\right)$ or to a series of compounds (5azacytidine, $100 \mu \mathrm{g} / \mathrm{ml}$; cycloheximide, $200 \mu \mathrm{g} / \mathrm{ml}$; ethidium bromide, $1000 \mu \mathrm{g} / \mathrm{ml}$; pyrazomycin, $200 \mu \mathrm{g} / \mathrm{ml}$ ) was first determined. Four other compounds, aranotin, 6-azauridine, mycophenolic acid and rifampicin, were also tested but were non-toxic to $P$. chrysogenum. Priority was given to treatment with compounds toxic to the host organism.

Survivors of treatment were selected at random and compared with the control culture for reduction in virus titre. Fungal extracts were initially screened with an immunodiffusion assay (Fig. I). In addition, all strains were compared with the control culture for ability to synthesize penicillin. Cultural characteristics such as relative growth and colony colouration were recorded for each isolate (Table I). All strains retained the ability to synthesize antibiotic, although considerable variation was observed among isolates with regards to net accumulation of penicillin and the $\mathrm{pH}$ profile during fermentation (Table I). Growth rate 


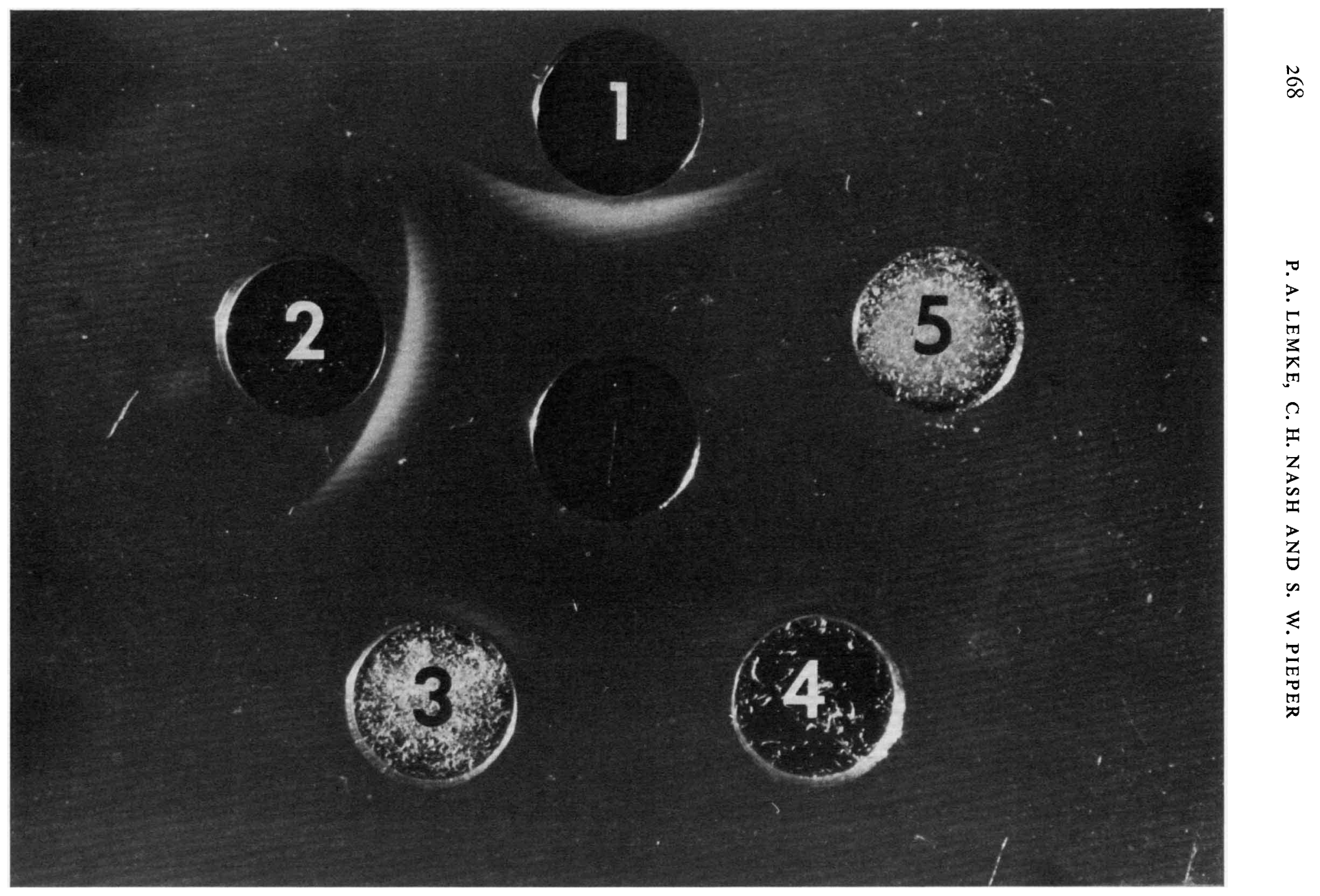

Fig. I. Ouchterlony double-diffusion assay of Penicillium chrysogenum mycophage: rabbit antiserum to purified virus (centre), purified virus (I), control strain (2), c6 strain (3), PI strain (4), and $\Delta 2$ strain (5). 
Table I. Strains of Penicillium chrysogenum derived from a virus-infected culture

\begin{tabular}{|c|c|c|c|c|c|c|c|}
\hline \multirow[b]{2}{*}{$\begin{array}{c}\text { Strain } \\
\text { Control (E-I 5) }\end{array}$} & \multirow[b]{2}{*}{ Treatment } & \multirow{2}{*}{$\begin{array}{c}\text { Immunodiffusion } \\
\text { assay } \\
\text { viral titre } \\
\text { Control }\end{array}$} & \multirow{2}{*}{$\begin{array}{l}\text { Relative growth } \\
\text { and colony } \\
\text { colouration } \\
\text { Control; green }\end{array}$} & \multicolumn{2}{|c|}{$\begin{array}{l}\text { Penicillin } \\
\text { production } \\
\% \text { control }\end{array}$} & \multicolumn{2}{|c|}{$\mathrm{pH}$} \\
\hline & & & & $\begin{array}{l}3 \text { days } \\
100\end{array}$ & $\begin{array}{l}7 \text { days } \\
100\end{array}$ & $\begin{array}{c}3 \text { days } \\
6.0\end{array}$ & $\begin{array}{c}7 \text { days } \\
6 \cdot 1\end{array}$ \\
\hline$\Delta \mathbf{I}$ & Heat & Reduced & Fast; dark green & I06 & 76 & $6 \cdot I$ & $5 \cdot 8$ \\
\hline$\Delta \mathbf{2}$ & & Absent & Fast; white & 38 & I 2 & $6 \cdot I$ & $8 \cdot 2$ \\
\hline$\Delta_{3}$ & & Absent & Fast; green & $4 \mathrm{I}$ & 25 & $6 \cdot I$ & $6 \cdot 0$ \\
\hline$\Delta_{4}$ & & Absent & Fast; beige & 49 & I I & $6 \cdot 3$ & $8 \cdot 0$ \\
\hline$\Delta 5$ & & Absent & Fast; dark green & 89 & $7 I$ & $6 \cdot 4$ & $5 \cdot 8$ \\
\hline$\Delta 6$ & & Absent & Fast; beige & $5 I$ & I 2 & $5 \cdot 7$ & $7 \cdot 9$ \\
\hline$\Delta 7$ & & Reduced & Fast; green & 82 & - & $5 \cdot 7$ & - \\
\hline$\Delta 8$ & & Reduced & Control; sectored & 132 & - & $5 \cdot 8$ & - \\
\hline$\Delta 9$ & & Reduced & Fast; green & 94 & 一 & $5 \cdot 7$ & - \\
\hline$\Delta \mathrm{IO}$ & & Reduced & Slow; light green & 103 & - & $5 \cdot 8$ & - \\
\hline$\Delta \mathrm{II}$ & & Reduced & Slow; white & 57 & 一 & $5 \cdot 7$ & - \\
\hline$\Delta \mathrm{I}_{2}$ & & Reduced & Fast; white & 57 & 一 & $5 \cdot 7$ & 一 \\
\hline AI & 5-Azacytidine & Control & Slow; pale green & 20 & I & $6 \cdot 4$ & $7 \cdot 2$ \\
\hline A2 & & Control & Control; green & 87 & 94 & $6 \cdot 0$ & $6 \cdot 2$ \\
\hline A3 & & Control & Control; green & 99 & 99 & $6 \cdot 0$ & 5.9 \\
\hline A4 & & Control & Slow; white & 77 & 22 & $6 \cdot 2$ & $6 \cdot 0$ \\
\hline A5 & & Control & Fast; green & 78 & 59 & $5 \cdot 9$ & $5 \cdot 7$ \\
\hline A6 & & Control & Fast; green & 85 & 60 & $6 \cdot 7$ & $6 \cdot 2$ \\
\hline $\mathrm{CI}$ & Cycloheximide & Reduced & Control; sectored & I 14 & 88 & $6 \cdot 2$ & $6 \cdot 0$ \\
\hline $\mathrm{C} 2$ & & Reduced & Fast; white & 120 & 95 & $6 \cdot 2$ & $6 \cdot 0$ \\
\hline $\mathrm{C} 3$ & & Control & Fast; dark green & 135 & $8 \mathrm{I}$ & $6 \cdot 0$ & $6 \cdot 5$ \\
\hline $\mathrm{C} 4$ & & Control & Fast; dark green & I 7 & 99 & $6 \cdot I$ & $6 \cdot 1$ \\
\hline C5 & & Reduced & Fast; sectored & 180 & 75 & $6 \cdot I$ & $6 \cdot 2$ \\
\hline c6 & & Reduced & Slow; sectored & 124 & 25 & $5 \cdot 9$ & $5 \cdot 9$ \\
\hline EBI & Ethidium bromide & Control & Control; green & IOI & $\ldots$ & - & - \\
\hline EB2 & & Control & Control; green & 102 & 一 & - & - \\
\hline EB3 & & Control & Control; green & I I 7 & - & 一 & -- \\
\hline EB4 & & Control & Control; green & I I 3 & - & 一 & $\ldots$ \\
\hline EB5 & & Control & Control; green & II 3 & - & - & - \\
\hline EB6 & & Control & Control; green & 89 & - & - & - \\
\hline PI & Pyrazomycin & Reduced & Control; green & 84 & 66 & $6 \cdot 2$ & $6 \cdot 0$ \\
\hline P2 & & Control & Slow; white & 70 & 97 & $6 \cdot I$ & $6 \cdot 4$ \\
\hline P3 & & Control & Slow; sectored & 70 & IOI & $6 \cdot 3$ & $6 \cdot 4$ \\
\hline $\mathrm{P} 4$ & & Control & Fast; dark green & 76 & 95 & $6 \cdot 2$ & $5 \cdot 8$ \\
\hline P5 & & Control & Fast; dark green & 86 & 98 & $6 \cdot 3$ & $6 \cdot 0$ \\
\hline P6 & & Control & Fast; green & 85 & 93 & $6 \cdot 2$ & $6 \cdot 0$ \\
\hline
\end{tabular}

and colony colouration varied considerably among isolates (Fig. 2). Such variation is known to occur spontaneously among isolates of Penicillium chrysogenum (Backus \& Stauffer, I955; Lemke \& Ness, 1970). However, a series of spontaneous variants of this organism assayed for virus by the immunodiffusion method proved to be uniformly infected. Only with successive heat treatments or following repeated treatments with either pyrazomycin or cycloheximide was an apparent reduction in intracellular virus titre observed (Table I, Fig. I).

Several strains were selected for further study. Extracellular as well as intracellular virus titres were measured with an immunochemical assay. In this assay viral nucleic acid was labelled with tritiated uracil, and the virus was selectively precipitated with rabbit antiserum to mycophage. This assay proved to be extremely sensitive, and with it three types of strains were recongized with regard to virus titre (Table 2). One strain type (i.e. $\Delta 2$ ) appeared 

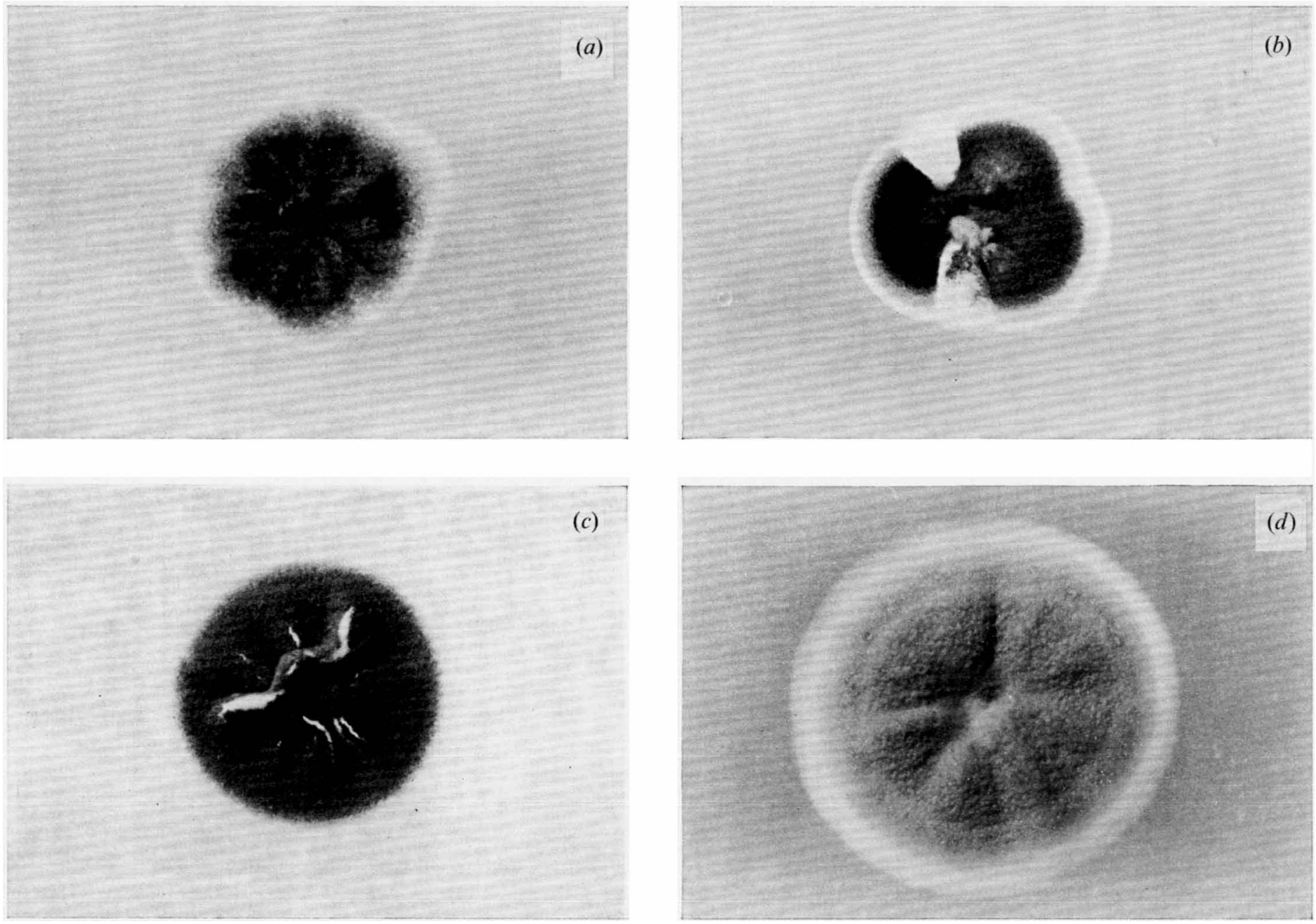

Fig. 2. Cultural characteristics of Penicillium chrysogenum: (a) control strain, green; (b) c6 strain, sectored; $(c) \Delta \mathrm{I}$ strain, dark green; $(d) \Delta 2$ strain, white. All cultures were photographed after 7 days of incubation and at the same magnification. 


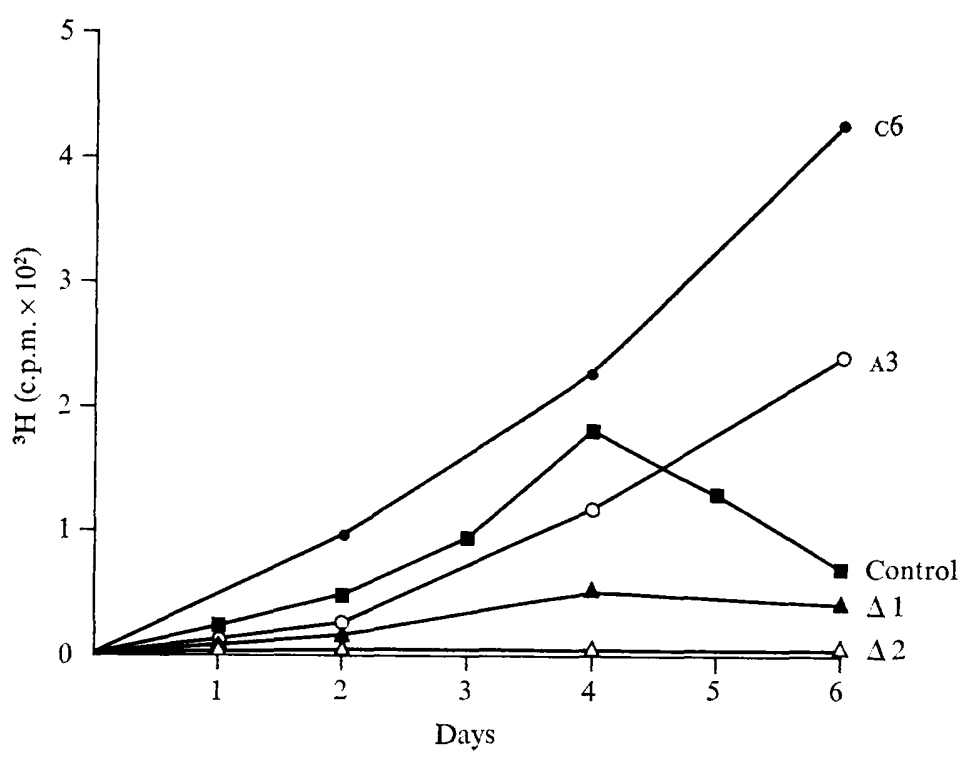

Fig. 3. Release of Penicillium chrysogenum mycophage during fermentation.

Table 2. Virus titre of broth and fungal extracts in four strains of Penicillium chrysogenum*

$\begin{array}{ccc}\text { Strain } & \text { Broth }+A b_{R M} \dagger & \text { Fugal extract }+A b_{R M} \\ \Delta_{I} & \text { Not tested } & 756 \\ \Delta_{2} & \text { Not tested } & 0 \\ \text { c6 } & 597 & 5332 \\ \text { Control } & 496 & 29053\end{array}$

\footnotetext{
* All values represent d.p.m. $/ 0.5 \mathrm{ml}$ of either broth or fungal extract.

$\dagger \mathrm{Ab}_{\mathrm{RM}}=$ rabbit antiserum to mycophage.
}

to be cured of virus, since no label was recovered through precipitation by the immunochemical assay. A second strain type (i.e. $\Delta \mathrm{I}$ ) exhibited reduction in virus titre. The third strain type (i.e. c6) exhibited an increased extracellular virus titre.

The extracellular titre of virus during fermentation was compared among strains of Penicillium chrysogenum (Fig. 3). Viral nucleic acid was again labelled with tritiated uracil, and broth samples in this instance were precipitated with trichloroacetic acid. The $\Delta \mathbf{2}$ strain was consistently negative for the release of virus, and the $\Delta \mathrm{I}$ strain, although infected, was reduced in virus titre. Two strains, $\mathrm{c} 6$ and $\mathrm{A} 3$, exhibited a marked increase in extracellular virus titre. Similar differences in titre were observed when extracellular virus was measured by immunoprecipitation.

Strains of Penicillium chrysogenum with increased extracellular virus titre form lytic plaques when grown on an unbuffered, high lactose-containing medium. On this medium erumpent patches of white sterile mycelia developed after 5 days of incubation (Fig. 4). These patches, however, were not formed by the $\Delta 2$ culture and were rarely observed with the $\Delta \mathrm{r}$ culture. Such patches were formed at a high frequency by other cultures (i.e. c6, PI, A3) and led to 

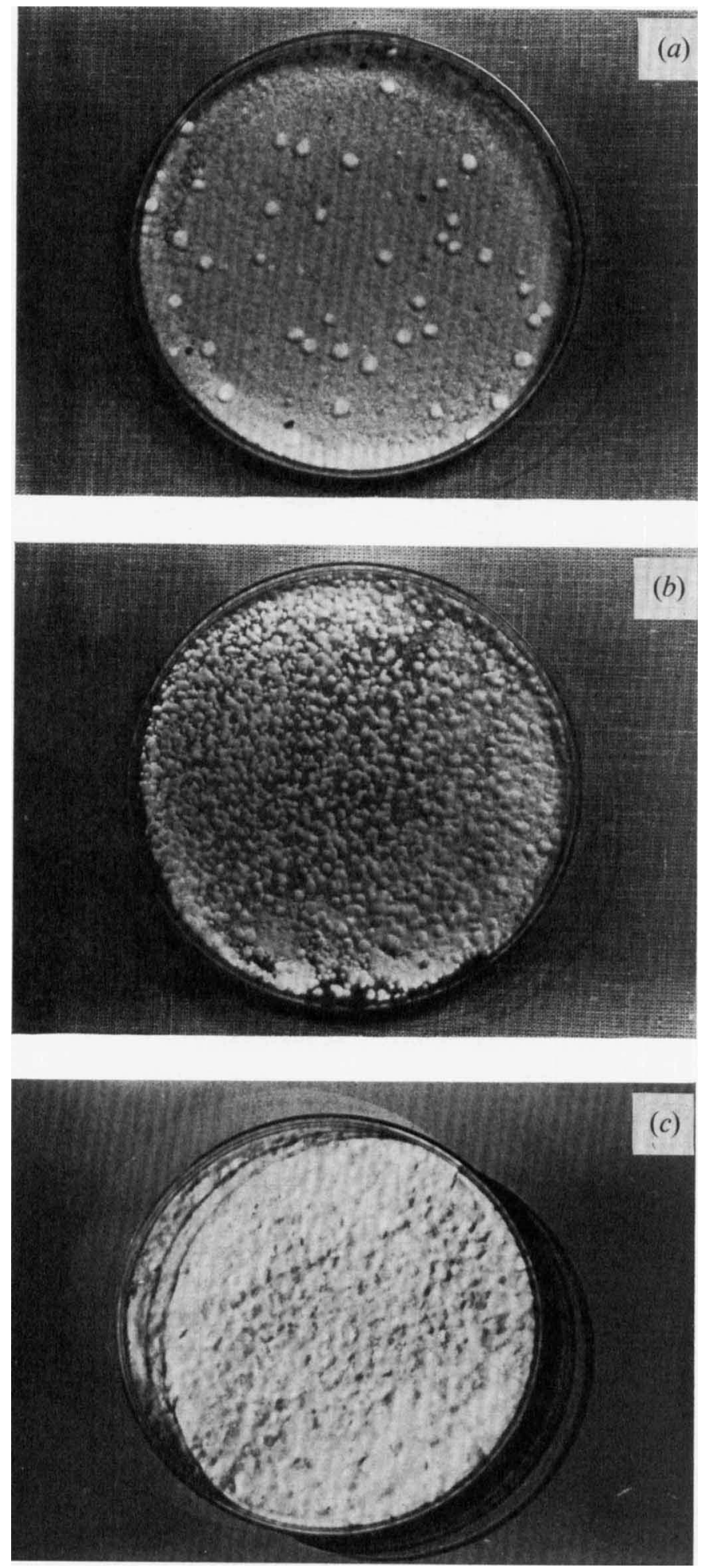

Fig. 4. Early (5-day) plaque formation in Penicillium chrysogenum: (a) control strain; (b) heavily infected A3 strain; (c) uninfected $\Delta 2$ strain. 

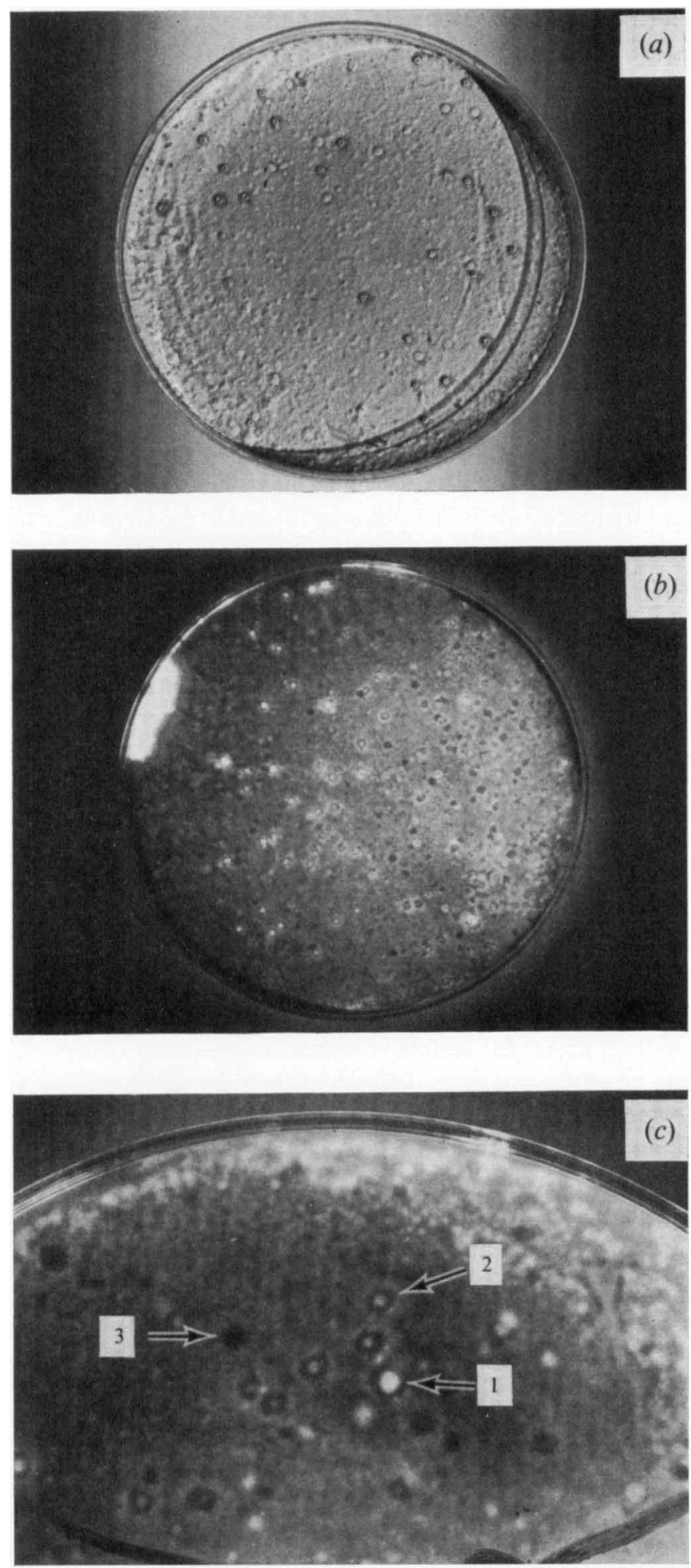

Fig. 5. Late plaque formation in Penicillium chrysogenum: (a) c6 strain, surface of culture after 2 weeks of incubation; $(b)$ c6 strain, after 4 weeks of incubation, bottom of Petri plate observed by transmitted light; $(c)$ close-up of $(b)$ arrows indicate differences in plaque morphology, i.e. clear (I), turbid with clear centre (2), and turbid (3). 
localized plaque formation after 4 weeks of incubation (Fig. 5). Plaques varied in morphology from clear to turbid (Fig. $5 c$ ).

\section{DISCUSSION}

Mycoviruses have now been reported in several genera representing all of the major taxonomic groups of fungi (Hollings \& Stone, I97I [review]; Day \& Ellis, I97I ; Lapierre, Albouy, Faivre-Amiot \& Molin, I97I ; Kazama \& Schornstein, 1972; Lapierre, FaivreAmiot, Kusiak \& Molin, 1972; Lhoas, 1972; Tuveson \& Peterson, 1972; Koltin, Berick, Stamberg \& Ben-Shaul, 1973). Several viruses from imperfect fungi have been studied in considerable detail and, in general, these viruses contain genomes of double-stranded ribonucleic acid. Among the viruses of imperfect fungi, those present in Penicillium stoloniferum and $P$. chrysogenum have been characterized most extensively (Banks et al. I968; Buck, Chain \& Darbyshire, I969; Buck \& Kempson-Jones, I970; Bozarth, Wood \& Mandelbrot, 197r; Wood \& Bozarth, 1972; Nash et al. 1973). Certain biological properties characteristic of viruses have now been demonstrated with the viruses of these two fungal species. Viral transmission through heterokaryosis and the native infection of protoplasts by virus have been described for $P$. stoloniferum (Lhoas, 197I $a, b$ ). An RNA-dependent RNA polymerase activity has been reported for viruses in both $P$. stoloniferum (Lapierre, Astier-Manifacier \& Cornuet, I97I) and $P$. chrysogenum (Nash et al. 1973).

We now report the isolation of strains of Penicillium chrysogenum altered with respect to virus titre. Some strains were greatly reduced for virus titre, and this reduction could be demonstrated by an immunodiffusion assay (Fig. I). One strain was isolated that was apparently freed of virus, since assay for virus by an extremely sensitive radioimmunological method proved negative (Table 2, Fig. 3). This strain can now be utilized in genetic studies of $P$. chrysogenum without the superimposition of a virus. Still other strains of $P$. chrysogenum contained high titres of virus, and these strains were lytic. These results demonstrate that the virus of $\boldsymbol{P}$. chrysogenum was not only variable in titre but was potentially virulent. It remains to be determined if this double-stranded RNA-containing virus can engage in genetic determination beyond its own replication.

Lytic plaques have been reported previously in two species of Penicillium infected by virus-like particles (Borré, Morgantini, Ortali \& Tonolo, 197I), and transmission of a cytoplasmic factor responsible for cellular breakdown has been observed in Schizophyllum commune (Koltin et al. 1973) and in a species of Aspergillus (Jinks, 1959; Caten, 1972). Our studies with Penicillium chrysogenum demonstrate for the first time that the extent of plaque formation in a fungus is related to virus titre.

Antiserum to purified virus of Penicillium chrysogenum was prepared with the cooperation of Dr R. E. Bowen, Greenfield Laboratories, Eli Lilly and Company.

\section{REFERENCES}

Backus, M. P. \& Stauffer, J. F. (1955). The production and selection of a family of strains in Penicillium chrysogenum. Mycologia 47, 429-463.

Banks, G. T., Buck, K. W., Chain, E. B., Darbyshire, J. E. \& Himmelweit, F. (1969). Virus-like particles in penicillin producing strains of Penicillium chrysogenum. Nature, London 222, 89-90.

Banks, G. T., Buck, K. W., Chain, E. B., Himmelweit, F., Marks, J. E., Tyler, J. M., Hollings, M., LAst, F. T. \& Stone, O. M. (1968). Viruses in fungi and interferon stimulation. Nature, London 218, $542-545$.

Borré, E., Morgantini, L. E., Ortali, V. \& Tonolo, A. (197I). Production of lytic plaques of viral origin in Penicillium. Nature, London 229, 568-569. 
Boxer, G. E. \& Everett, P. M. (1949). Colorimetric determination of benzyl-penicillin. Analytical Chemistry 2r, 670-673.

Bozarth, R. F., Wood, H. A. \& Mandelbrot, A. (I97I). The Penicillium stoloniferum virus complex. Two double-stranded RNA virus-like particles in a single cell. Virology 45, 516-523.

Buck, K. W., Chain, E. B. \& Darbyshire, J. E. (1969). High cell wall galactosamine content and virus particles in Penicillium stoloniferum. Nature, London 223, I 273.

Buck, K. W., Chain, E. B. \& Himmelweit, F. (197I). Comparison of interferon induction in mice by purified Penicillitm chrysogenum virus and derived double-stranded RNA. Journal of General Virology 12, I 3 I-I 39 .

Buck, K. W. \& Kempson-Jones, G. F. (1970). Three types of virus particle in Penicillium stoloniferum. Nature, London 225, 945-946.

CATEN, C. E. (1972). Vegetative incompatibility and cytoplasmic infection in fungi. Journal of Genera Microbiology 72, 221-229.

Day, L. E. \& Ellis, L. F. (I971). Virus-like particles in Cephalosporium acremonium. Applied Microbiology 22, 919-920.

Elander, R. P. (1967). Enhanced penicillin biosynthesis in mutant and recombinant strains of Penicillium chrysogenum. In Induced Mutations and Their Utilization, pp. 403-423. Abhandlungen der Deutschen Akademie der Wissenschaften zu Berlin.

Hollings, M. \& Stone, O. M. (I97I). Viruses that infect fungi. Annual Review of Phytopathology 9, 93-I I 8.

Horwitz, M. S. \& SCHARFF, M. D. (1969). Immunological precipitation of radioactively labelled viral proteins. In Fundamental Techniques in Virology. Edited by K. Habel and N. P. Salzman. New York: Academic Press.

JiNks, J. L. (1959). Lethal suppression cytoplasms in aged clones of Aspergillus glaucus. Journal of General Microbiology 21, 397-409.

KaZAma, F. Y. \& Schornstein, K. L. (1972). Herpes-type virus particles associated with a fungus. Science, New York $\mathbf{1 7 7}, 696-697$.

Koltin, Y., Berick, R., Stamberg, J. \& Ben-Shaul, Y. (I973). Virus-like particles and cytoplasmic inheritance of plaques in a higher fungus. Nature New Biology 24r, 108-I09.

Lapierre, H., Albouy, J., Faivre-Amiot, A. \& Molin, G. (I97I). Mise en évidence de particules virales dans divers champignons du genre Sclerotium. Comptes rendus de l'Academie des sciences (Ser D.) 272, 2848-285I.

LAPIERre, H., Astier-Manifacier, S. \& Cornuet, P. (I97I ). Activité RNA polymérase associée aux préparations purificés de virus du Penicillium stoloniferum. Comptes rendus de l'Académie des sciences (Ser D.) 273, 992-994.

Lapierre, H., Faivre-Amiot, A., Kusiak, C. \& Molin, G. (1972). Particules de type viral associées au Mycogone perniciosa Magnus, agent d'une des môles du champignon de couche. Comptes rendus de l'Académie des sciences (Ser D.) 274, I867-1870.

LEMKE, P. A. (1969). A century of compounds and their effect on fungi. Mycopathologia et mycologia applicata 38, 49-49.

Lemke, P. A. \& Ness, T. M. (1970). Isolation and characterization of a double-stranded ribonucleic acid from Penicillium chrysogenum. Journal of Virology 6, 813-819.

LHOAS, P. (197I $a$ ). Infection of protoplast from Penicillium stoloniferum with double-stranded RNA viruses. Journal of General Virology 13, 365-367.

LhoAs, P. (I97 1 b). Transmission of double-stranded RNA viruses to a strain of Penicillium stoloniferum through heterokaryosis. Nature, London 230, 248-249.

LHOAs, P. (1972). Mating pairs of Saccharomyces cerevisiae infected with double stranded RNA viruses from Aspergillus niger. Nature, London 236, 86-87.

Moss, M. O. \& COLE, M. (1964). Reaction of 6-aminopenicillanic acid with carbohydrates and related substances. Biochemical Journal 92, 643-648.

Nash, C. H., Douthart, R. J., Ellis, L. F., Vanfrank, R. M., Burnett, J. P. \& Lemke, P. A. (I973). On the mycophage of Penicillium chrysogenum. Canadian Journal of Microbiology 19, 97-103.

Sermonti, G. (I957). Analysis of vegetative segregation and recombination in Penicillium chrysogenum. Genetics 42, 433-443.

Tuveson, R. W. \& Peterson, J. F. (1972). Virus-like particles in certain slow-growing strains of Neurospora crassa. Virology 47, 527-53I.

Vanderhaeghe, H., Claesen, M., Vlietinck, A. \& Parmentier, G. (1968). Specificity of penicillin acylase of Fusarium and of Penicillium chrysogenum. Applied Microbiology 16, I 557-1 563.

Wood, H. A. \& Bozarth, R. F. (1972). Properties of virus-like particles of Penicillium chrysogenum: One double-stranded RNA molecule per particle. Virology 47, 604-609. 